Animal Healthy Research Institute,

New-Valley Laboratory

\title{
INCIDENCE OF INTERNAL PARASITES OF DESERT GOATS IN NEW VALLEY, EGYPT
}

(With 5 Tables and 4 Figures)

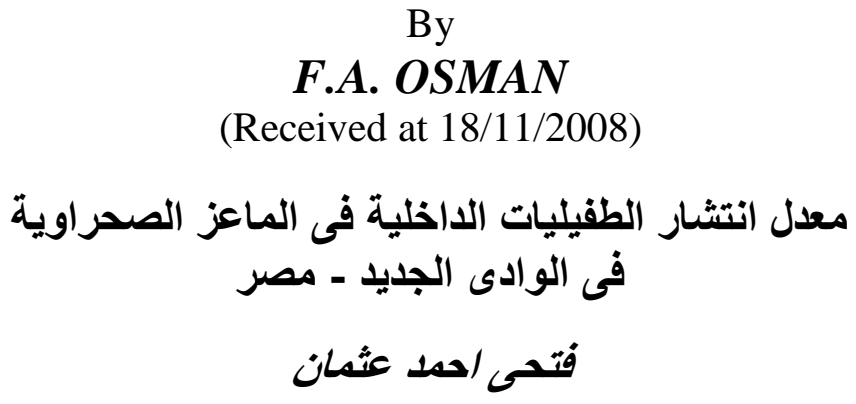

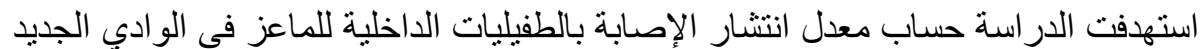

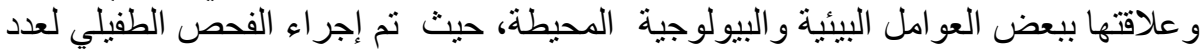

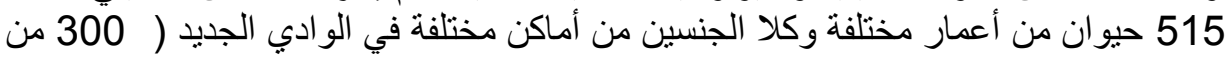

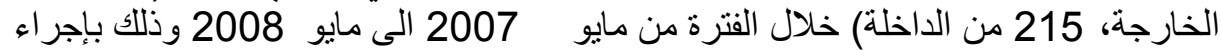

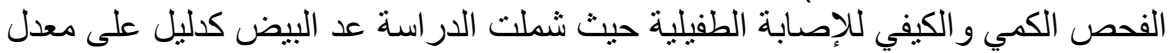

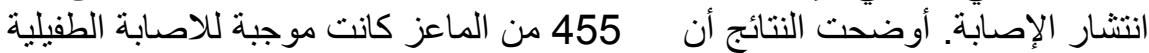

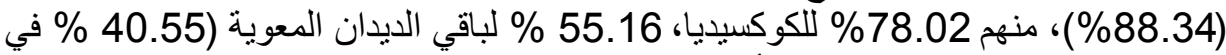

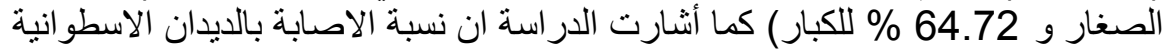

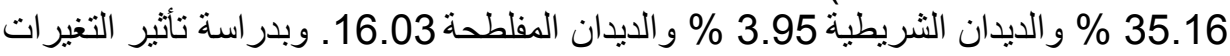

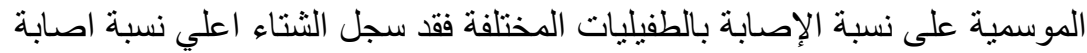

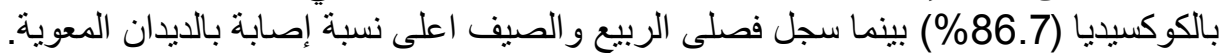

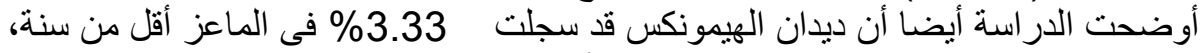

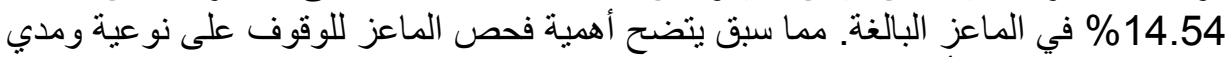

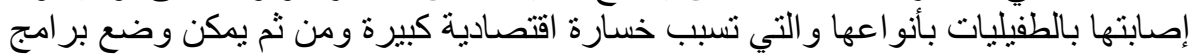

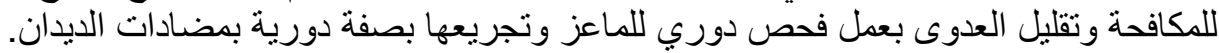

\section{SUMMARY}

The study was carried out on 515 goats from different localities in New Valley governorate with different ages and sexes during the period from May 2007 to May 2008. The study aimed to monitor parasitic infection among these goats qualitatively and quantitively. The results proved that 455 goats infected with different gastrointestinal parasites $(88.34 \%)$ where Eimeria spp. was representing an incidence of $78.02 \%$ while the total infection rate of different helminthes was $55.16 \%$ (40.55\% in kids 
and $64.72 \%$ in Adult). The infection rates were 35, $16 \%$ for Nematodes, $3.95 \%$ for Cestods, $16.03 \%$ for Trematods. The study declared that parasitic infection represents a major health impact on goats at New Valley with special reference to Eimeria spp. and Hemonchus contortus in both young and adults. The influence of seasonal variation proved higher coccidial infection at winter $(86.7 \%)$, however higher intestinal helminths infection were found at spring and summer. It could be concluded that periodical parasitic examination of goats in New Valley should be attempted to recognize and manage parasitic infection.

Key words: Internal, parasite, goats, New Valley

\section{INTRODUCTION}

Internal parasites of goats are considered one of the biggest problems where it can cause major health issues, which have a major effect on the animal performance and causes great economic losses not due to mortality but due to production loss (Waller, 2004). The proper management of the internal parasites is extremely important to effectively reduce the herd exposure to parasites.

One of the first things that producer should realize, that goats are naturally browsers in contrast to sheep and cattle which are grazers. Additionally goats have traditionally been raised in dry-arid climate in extensive production systems and they simply have not had opportunity to adapt to the warm-moist condition of a humid climate. All of these factors in addition to the fact that many of the parasites that affect goats thrive in warm, moist condition and live close to the ground (Waller, 2004). Gastrointestinal nematode infection can be treated by anthelmintic chemotherapy; however, treatment costs and drug resistance has elevated in all major parasite species (Ross 1997, Zajac and Gipson 2000 and Veale 2002). Compared to sheep, which develop a strong natural immunity around 12 months of age, goats acquire a lower level of immunity to gastrointestinal parasites. This explain why goats having greater populations of adult parasites with high egg output. In experimental Teladorsagia (Ostertagia) circumcincta infection (Macaldowie et al. 2003) found that goats carried higher worm burden than lambs and there were significant differences in the stages of development attained by the larval challenge established in the two species. Mullerius capillaris was reported to cause Verminous bronchitis among goats causing sever losses (Bruce et al., 1986) 


\section{MATERIALS and METHODS}

\section{Animals (Table 1):}

The study was carried out on 515 goats (different ages and sexes) of native breed from various regions of New-valley Governorates (300 goats from El-Kharga and 215 from El-Dakhla). In order to properly manage a herd, it is important to be able to recognize the signs of parasitism. Diagnosis is usually done by observing the clinical signs and performing a fecal egg count test.

A- Observing the clinical signs:

Diseased goats were usually isolated from the herd and do not eat normally. Daily visual inspection is usually sufficient to monitor for parasitic infection.

B- Other diagnostic methods such as a fecal egg counts must also be routinely done since the biggest impact of internal parasites occur in the sub clinical level (not easily detected by visual observation) (Waller and Thramsborg, 2004).

\section{Sampling:}

Fecal samples were collected directly from the rectum or immediately after defecation, then kept in clean plastic sac, labeled with the required data concerning age, sex, date of collection and any apparent clinical signs, then sent to the diagnostic laboratory.

\section{Gross examination of samples:}

Fecal samples were grossly examined for color, consistency, presence of mucous, blood, indigested feed and parasites (intact parasite, and / or larvae or gravid segments of Cestodes (Charles 1998).

\section{Parasitological examination:}

Fecal samples were examined by using floatation technique in saturated $\mathrm{NaCl}$ solution for detection of Nematode and Cestode eggs (Burger and stoy, 1968) and sedimentation technique for detection of Trematode eggs (Charles 1998). Egg count was done by using McMaster counting slide (Seivwright et al., 2004 and Pereckienè et al., 2007)

\section{Fecal culture:}

In order to assess species of gastrointestinal nematodes, samples of feces from individual animals were cultured for third stage larval development (Christie and Jackson, 1982). After 7 days of incubation larvae from cultures were harvested and identified to genera or species using light microscope. Baerman s technique was used for detection of 
lung worm infection. Identification of the collected eggs and larvae was done according to Dunn, (1978) and Soulsby (1982).

\section{RESULTS}

In the present study 515 goats with variable ages, sexes and seasons were selected from different localities in New Valley Governorate during the peried of one year, Table (1).

\section{A- Observed clinical signs:}

Some of the observable clinical signs of heavy internal parasite infection are anemia, bottle-jaw and wasting away or poor weight gain, anemia results from blood sucking parasites is clearly observed in scleral and oral mucus membranes.

\section{B- Parasitological findings (Tables 2-5 and Fig. 1-4):}

As many as $88.34 \%$ of examined goats were infected with at least one genus/species of parasite. In this study Eimeria infection was the most prevalent parasitic infection $(78.02 \%)$ where its rate in young $<1$ year was $75 \%$ and $80 \%$ in adults. Helminthes infection was detected in $55.6 \%$ of totally examined goats with infection rates of 40.55 and $64.72 \%$ in young and adult respectively (Table 2).

Strongyloid like eggs were the most predominant nematodes observed in the examined fecal samples $(25.93 \%)$ but in fecal culture the most predominant worms were Hemonchus spp., Chabertia spp., Trichostrongylus spp., Ostertagia spp. and Oesphogastomum spp. Their infection rate was $10.10,5.93,5.49,4.6,3.07 \%$ respectively (Table 5). Fasciola eggs (Trematode) were detected only in adult goats in ratio of $12.74 \%$ and Cestodes infection were detected in $3.95 \%$ of examined goats (Table 3). Rate of infection was higher in female (94.52\%) than in males $(79.02 \%)$ as in Table 6 .

Concerning to the seasonal variation, the incidence of Eimeria was the most prevalent parasitic infection allover the year, where it was ranged from $(86.72 \%)$ in winter to $(68.96 \%)$ in spring, but Nematode increase gradually at autumn and reach to the high level of infection in winter and spring but low level of infection indicated in summer (Table 4).

Table 1: The goats selected for the study.

\begin{tabular}{|c|c|c|c|c|}
\hline Items & No. & Sex & Age & Season \\
\hline
\end{tabular}


Assiut Vet. Med. J. Vol. 55 No. 120 January 2009

\begin{tabular}{|c|c|c|c|c|c|c|c|c|c|c|}
\hline \multicolumn{2}{|c|}{ Localities } & & $\mathrm{M}$ & $\mathrm{F}$ & $<1 \mathrm{Y}$ & $>1$ & Win & Spr. & Sum & $\overline{\mathrm{Aut}}$ \\
\hline \multirow{6}{*}{$\begin{array}{l}\text { El- } \\
\text { Kharga }\end{array}$} & El-Monera & 59 & 34 & 25 & 30 & 29 & 15 & 14 & 15 & 15 \\
\hline & El-Thawra & 47 & 20 & 27 & 17 & 30 & 11 & 11 & 13 & 12 \\
\hline & Boulak & 56 & 16 & 40 & 16 & 40 & 14 & 14 & 14 & 14 \\
\hline & El-Rawad & 60 & 20 & 40 & 18 & 42 & 15 & 15 & 15 & 15 \\
\hline & Darb-El arbin & 78 & 20 & 58 & 36 & 42 & 19 & 20 & 20 & 19 \\
\hline & Total & 300 & 110 & 190 & 117 & 183 & 74 & 74 & 77 & 75 \\
\hline \multirow{5}{*}{\begin{tabular}{|l} 
El- \\
Dakla
\end{tabular}} & El-Hendaw & 56 & 20 & 36 & 20 & 36 & 14 & 14 & 14 & 14 \\
\hline & El-Rashda & 48 & 10 & 38 & 26 & 22 & 12 & 12 & 12 & 12 \\
\hline & El-Maashra & 41 & 8 & 33 & 19 & 22 & 10 & 10 & 10 & 11 \\
\hline & $\begin{array}{l}\text { West-El } \\
\text { Mowhoub }\end{array}$ & 70 & 20 & 50 & 28 & 42 & 17 & 17 & 18 & 18 \\
\hline & Total & 215 & 58 & 157 & 93 & 122 & 53 & 53 & 54 & 55 \\
\hline
\end{tabular}

Table 2: Prevalence of parasitic infection in examined goats in New Valley Governorate.

\begin{tabular}{|c|c|c|c|c|c|c|c|c|c|c|c|c|c|}
\hline \multirow{2}{*}{$\begin{array}{c}\text { Item } \\
\text { Animals }\end{array}$} & \multirow[t]{2}{*}{ No. } & \multicolumn{2}{|c|}{$\begin{array}{l}\text { Infected } \\
\text { animals }\end{array}$} & \multicolumn{2}{|c|}{$\begin{array}{c}\text { Single } \\
\text { coccidian }\end{array}$} & \multicolumn{2}{|c|}{$\begin{array}{c}\text { Single } \\
\text { helminth }\end{array}$} & \multicolumn{2}{|c|}{$\begin{array}{c}\text { Mixed } \\
\text { infection }\end{array}$} & \multicolumn{2}{|c|}{$\begin{array}{c}\text { Total } \\
\text { coccidia }\end{array}$} & \multicolumn{2}{|c|}{$\begin{array}{c}\text { Total } \\
\text { helminth }\end{array}$} \\
\hline & & N. & $\%$ & N. & $\%$ & $\mathrm{~N}$. & $\%$ & N. & $\%$ & $\mathrm{~N}$. & $\%$ & $\mathrm{~N}$. & $\%$ \\
\hline$<1$ Year & 210 & 180 & 85.7 & 107 & 59.44 & 45 & 25 & 28 & 15.55 & 135 & 75 & 73 & 40.55 \\
\hline$>1$ Year & 305 & 275 & 90.6 & 97 & 35.27 & 55 & 20 & 123 & 44.72 & 220 & 80 & 178 & 64.72 \\
\hline Total & 515 & 455 & 88.4 & 204 & 44.83 & 100 & 21.97 & 151 & 33.18 & 355 & 78.62 & 251 & 55.16 \\
\hline
\end{tabular}

Table 3: Prevalence of parasitic infection with relationship of age in examined goats.

\begin{tabular}{|c|c|c|c|c|c|c|}
\hline Items & $\begin{array}{r}\text { Youl } \\
1\end{array}$ & $\begin{array}{l}\text { 1year } \\
80)\end{array}$ & & $\begin{array}{l}\text { ult } \\
75)\end{array}$ & & $\begin{array}{l}\text { tal } \\
55)\end{array}$ \\
\hline Parasite & $\mathrm{N}$. & $\%$ & N. & $\%$ & N. & $\%$ \\
\hline $\begin{array}{l}\text { Nematodes: } \\
\text { - Toxocara Vitulorum } \\
\text { - MuelleriusCapillaris } \\
\text { - Trichuris ovis } \\
\text { - Strongyloids like eggs }\end{array}$ & $\begin{array}{c}5 \\
2 \\
8 \\
48\end{array}$ & $\begin{array}{c}2.77 \\
1.11 \\
4.44 \\
26.66\end{array}$ & $\begin{array}{c}---- \\
18 \\
9 \\
70\end{array}$ & $\begin{array}{l}---- \\
6.54 \\
3.27 \\
25.4\end{array}$ & $\begin{array}{c}5 \\
20 \\
17 \\
118\end{array}$ & $\begin{array}{l}1.09 \\
4.93 \\
3.73 \\
25.9 \\
\end{array}$ \\
\hline $\begin{array}{l}\text { Cestode. } \\
\text { Monezia.spp. }\end{array}$ & 5 & $2.77 \%$ & 13 & 4.72 & 18 & 3.95 \\
\hline $\begin{array}{l}\text { Trematode. } \\
\text { - Fasciola spp. } \\
\text { - Paramphistomum spp. }\end{array}$ & - & ------ & $\begin{array}{l}58 \\
10\end{array}$ & $\begin{array}{c}21.09 \\
3.63\end{array}$ & $\begin{array}{l}58 \\
15\end{array}$ & $\begin{array}{c}12.74 \\
3.29\end{array}$ \\
\hline $\begin{array}{l}\text { Protozoa. } \\
\quad \text { Eimera. spp. }\end{array}$ & 135 & $75 \%$ & 220 & $72.13 \%$ & 355 & 78.02 \\
\hline
\end{tabular}

Table 4: Seasonal variation with different parasite in examined goats. 


\begin{tabular}{|c|c|c|c|c|c|c|c|c|}
\hline & $\mathrm{N}$ & $\%$ & $\mathrm{~N}$ & $\%$ & $\mathrm{~N}$ & $\%$ & $\mathrm{~N}$ & $\%$ \\
\hline $\begin{array}{l}\text { Nematades: } \\
\text { - Toxocara.vitillorum } \\
\text { - Muellerius capillaries. } \\
\text { - Trichurs. ovis } \\
\text { Strongylidea like eggs } \\
\text { 1. H. contortus. } \\
\text { 2. Ostertagia.spp. } \\
\text { 3. Chabertia. } \\
\text { 4. Oesphogastomum }\end{array}$ & 5 & $\begin{array}{l}--- \\
2.6 \\
5 \\
--- \\
- \\
4.4 \\
2 \\
0.9 \\
-- \\
- \\
1.8\end{array}$ & $\begin{array}{l}1 \\
3 \\
2 \\
1 \\
0 \\
6 \\
5 \\
5\end{array}$ & $\begin{array}{l}0.9 \\
2.6 \\
5 \\
1.7 \\
6 \\
- \\
8.8 \\
4 \\
5.3 \\
4.4 \\
2 \\
4.4 \\
2\end{array}$ & $\begin{array}{c}2 \\
0 \\
6 \\
1 \\
3 \\
5 \\
--\end{array}$ & $\begin{array}{l}2.65 \\
6.2 \\
7.07 \\
- \\
17.6 \\
9 \\
5.3 \\
11.5 \\
4.42\end{array}$ & $\begin{array}{l}5 \\
- \\
1 \\
1 \\
8 \\
8 \\
9 \\
2\end{array}$ & $\begin{array}{l}0.9 \\
4.3 \\
4.3 \\
- \\
9.5 \\
6.9 \\
7.8 \\
4.3\end{array}$ \\
\hline Cestodes: Moniezia.spp. & 3 & 2.7 & 4 & 3.5 & 2 & 1.8 & 9 & 7.8 \\
\hline $\begin{array}{l}\text { Trematode: } \\
\text { - } \quad \text { Fasciola. } \text { spp. } \\
\text { - } \quad \text { Paramphistomum.spp. }\end{array}$ & $\begin{array}{l}1 \\
8\end{array}$ & $\begin{array}{l}- \\
15 . \\
9 \\
---\end{array}$ & $\begin{array}{l}- \\
1 \\
6 \\
5\end{array}$ & $\begin{array}{l}- \\
14 . \\
2 \\
4.4\end{array}$ & $\begin{array}{l}2 \\
0\end{array}$ & $\begin{array}{l}- \\
17.6 \\
9 \\
1.8\end{array}$ & $\begin{array}{l}- \\
1 \\
5 \\
1 \\
1\end{array}$ & $\begin{array}{l}- \\
12 . \\
9 \\
9.5\end{array}$ \\
\hline Protozoa: Eimeria.spp. & $\begin{array}{l}8 \\
2 \\
\end{array}$ & $\begin{array}{l}72 . \\
6\end{array}$ & $\begin{array}{l}9 \\
5 \\
\end{array}$ & $\begin{array}{l}84 . \\
1 \\
\end{array}$ & $\begin{array}{l}9 \\
8 \\
\end{array}$ & 86.7 & $\begin{array}{l}8 \\
0 \\
\end{array}$ & $\begin{array}{l}68 . \\
9\end{array}$ \\
\hline
\end{tabular}

Table 5: Prevalence of helminthes detected by fecal culture in examined goats.

\begin{tabular}{|l|c|c|c|c|c|c|l|}
\hline \multirow{2}{*}{ Parasitic species } & \multicolumn{2}{|c|}{$\begin{array}{c}\text { Young } \\
\text { N (180) }\end{array}$} & \multicolumn{2}{|c|}{$\begin{array}{c}\text { Adult } \\
\text { N (275) }\end{array}$} & \multicolumn{2}{|c|}{ Total } & $\begin{array}{l}\text { Characteristic of } \\
\text { infective larvae }\end{array}$ \\
\cline { 2 - 7 } & $\mathrm{N}$. & $\%$ & $\mathrm{~N}$. & $\%$ & $\mathrm{~N}$. & $\%$ & \\
\hline Trichostrongylus spp. & 5 & 2.77 & 20 & 7.27 & 25 & 5.49 & $\begin{array}{l}\text { Short straight larva } \\
\text { with small tubercle, } \\
\text { conical tail sheath }\end{array}$ \\
\hline Oesphogastomum spp. & 4 & 2.22 & 10 & 3.63 & 14 & 3.07 & $\begin{array}{l}\text { Simple pointed long } \\
\text { tail }\end{array}$ \\
\hline Chabertia spp. & 7 & 3.88 & 20 & 7.27 & 27 & 5.93 & $\begin{array}{l}\text { The larva has 32 } \\
\text { rectangular intestinal } \\
\text { cells }\end{array}$ \\
\hline Hemonchus spp.. & 6 & 3.33 & 40 & 14.54 & 46 & 10.10 & $\begin{array}{l}\text { Head bullet-shaped } \\
\text { and has pointed tail }\end{array}$ \\
\hline Ostertagia spp. & - & - & 21 & 7.63 & 21 & 4.6 & $\begin{array}{l}\text { Conical, finger like } \\
\text { tail }\end{array}$ \\
\hline
\end{tabular}

Table 6: Prevalence of parasitic infection in relation to sex of examined goats. 


\begin{tabular}{|l|l|c|c|c|}
\hline Animals & Sex & No. of examined & \multicolumn{2}{|c|}{ Positive cases } \\
\cline { 3 - 5 } & & goats & No. & $\%$ \\
\hline \multirow{3}{*}{ Goats } & Females & 310 & 293 & $94.52 \%$ \\
\cline { 2 - 5 } & Males & 205 & 162 & $79.02 \%$ \\
\cline { 2 - 5 } & Total & 515 & 455 & $88.34 \%$ \\
\hline
\end{tabular}

\section{FIGURES}

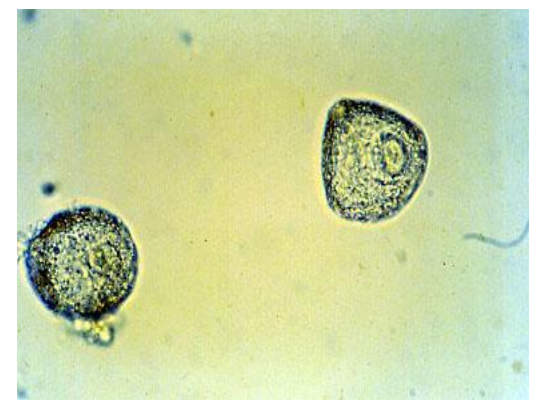

Fig. 1: Moniezia spp. eggs

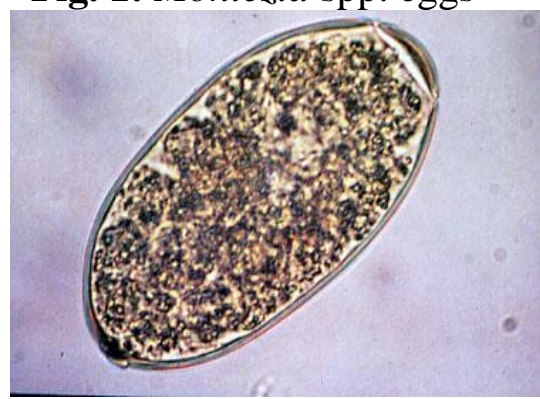

Fig. 3 : Fasciola spp. egg

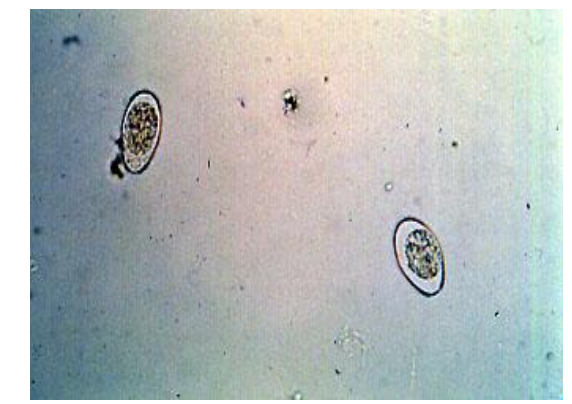

Fig. 2: Eimeria ovis

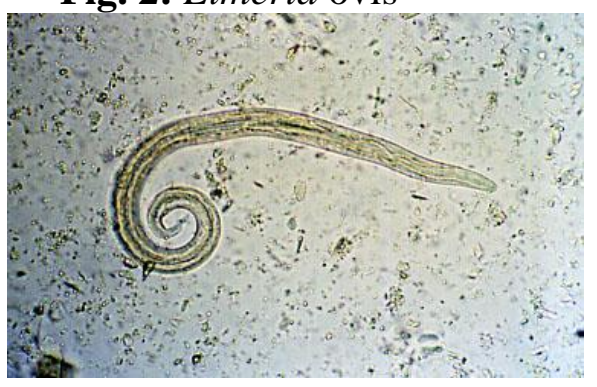

Fig. 4: Muellerius capillaris larva

\section{DISCUSSION}

The results of the present study supports the opinion that goats acquire a lower level of immunity to gastrointestinal parasites than other ruminant. The infection with Eimeria spp. (Coccidia) result in serious clinical signs of fluid diarrhea which may or may not contain mucus or blood, dehydration, weakness, loss of appetite and death while some goats may instead be constipated and suddenly die without diarrhea.

Coccidian parasites were detected in $90.3 \%$ at Saudi Arabia (Alyousif et al., 1992) and 94.65\% of examined goats in Egypt (Otify, 1984). Eimeria oocyst are widly present in feces of both normal and diseased goats in a reported range of $38 \%$ to $100 \%$ of all goats (Smith and Sherman, 1994). One of the most prevalent infection of 
Trichostrongyloid nematodes was Hemonchus Contortus (blood sucking worm) and Muellerius capillaries which is associated with marked tissue damage and pronounced cellular reaction. These results agreed with Berrag et al. (1997).

Bottle-jaw in gastrointestinal parasite infection is caused by hypoalbuminemia that results from either decreased feed intake, lack of appetite and increase the demands of proteins (Ashraf and Nepote 1990 and Min et al., 2005). The absence of Fasciola infection in young goats agree with the same result of (El-Sherif and Abo-EL- Hadid, 2005 and Mohsen and Ibrahim., 2008). Concerning the relationship between the sexes of examined goats and the infection rate, females were highly infected than males and this may be attributed to the fact that females are exposed to more stress like, pregnancy, lactation and parturition. These results agreed with those of Abd el- Wahed (1987).

Concerning the seasonal dynamics of parasitic helminthes infection, the study revealed that the incidence of nematode increase gradually at autumn and reach to the peak in winter and spring, but low level of infection observed in summer. This pattern may be attributed to the spring rise phenomena but the infective stage of most Strongyloid worm not resist the hot dry season. This phenomena mentioned by Herd (1971) as the end of winter and beginning of spring is considered as the peak of reproduction and maturation of their inhibited larvae takes place in spring season which known as spring rise.

\section{REFERENCES}

Abd El-Wahed, M.M. (1987): Morphological studies on gastrointestinal nematode infesting buffaloes in Kalubia and Sharkia Governorate. M. V. Sc. Thesis, Cairo University.

Alyousif, M.S.; Kasim, A.A. and Shawa, Y.R. (1992): Coccidiosis in domestic goats (Cabrahiricus) in Saudi Arabia. Inter. J. Parasitology, 22 (6) 807-811.

Ashraf, M. and Nepote, K.H. (1990): Prevalence of gastrointestinal nematodes, coccidian and lung worms in Maryland dairy goats. Small Ruminant Research, 3, 291-298.

Berrag, B.; Rhalem, A.; Sahibi, H.; Dorchies, P. and Cabaret, J. (1997): Bronchoalveolar cellular responses of goats Following infections with Muellerius Capillaris (Protostrongylidae Nematode). Veterinary immunology and immunopathology, $58,77-88$. 
Bruce, M. McCraw and Paula, I. Menzies (1986): Treatment of Goats Infected with the Lungworm Muellerius capillaries. Can Vet. J.; 27(8): 287-290

Burger, H.J. and Stoy, M. (1968): Parasitologische diagnostic (Teil 11) Elzahlung und larven differeniekung. Therapogen praxid dienst, 3, 1-22.

Charles, M. (1998): Diagnostic veterinary parasitology, second Edition, page 245-254.

Christie, M. and Jackson, F. (1982): Specific identification of strongyle egg in small samples of sheep feces. Research in Veterinary Science, 32, 113-117.

Dunn, A.M. (1978): Veterinary Helminthelogy. $2^{\text {nd }}$ Ed. Butter and Tanner lid, frome and Landon. Pp. 295-304.

El sheriff, A.M. and Abo-El Hadid, S.M. (2005): Episoatiological investigation about different internal parasitic affection among cattle calves in Beni-Suef Governorate. J. Egypt. Vet. Med. Ass., 65 (6) 261-274.

Herd, R.P. (1971): The parasitic life cycle of Chabertia ovina in sheep. Internal J. Parasitology, 1, 189-199.

Macaldowie, C.; Jackson, F.; Huntley, J.; Mackellar, A. and Jackson, E. (2003): A comparison of larval development and mucosal mast cell responses in worm-naïve goat yearlings, kids and lambs undergoing primary and secondary challenge with Teladorsagia circumcincta. Veterinary parasitology, 114, 1-13.

Min, B.R.; Hart, S.P.; Miller, D.; Tomita, G.M.; Loetz, E. and Sahlu, (2005): The effect of grazing forage containing condensed Tannis on gastrointestinal parasite infection and milk composition in Angoro does. Veterinary Parasitology, 130, 105-113.

Mohsen, I.A. and Ibrahim, A. (2008): Studies on some internal parasites of goats in Assiut Governorate especially which affecting liver. Assiut University. Bull. Environmental Research, 11: (1) 57-71.

Otify, Y.Z. (1984): Studies on Coccidian parasites of goats. Ph. D. Fac. Vet. Med. Alex. University.

Pereckienè, A.; Kaziūnaitè, V.; Vyšniauskas, A.; Petkevičius, S.; Malakauskas, A.; Šarkūnas, M. and Taylor, M.A. (2007): A comparison of modifications of the McMaster method for the enumeration of Ascaris suum eggs in pig faecal samples 
Veterinary Parasitology Volume 149, Issues 1-2, Pages 111116.

Roos, M.H. (1997): The role of drug in the control of parasitic nematode infections, must we do without parasitology, 114, 137-144.

Seivwright, L.J.; Redpath ${ }^{a .1}$, S.M.; Mougeot, F.; Watt. L. and Hudson, P.J. (2004): Faecal egg counts provide a reliable measure of Trichostrongylus tenuis intensities in free-living red grouse Lagopus lagopus scoticus. Journal of Helminthology, 78: 69-76 Cambridge University Press doi:10.1079/JOH2003220 Published online by Cambridge University Press 22 Feb 2007

Smith, M.C. and Sherman, D.M. (1994): Goat Medicine $1^{\text {st }}$ Ed. Lea Febiger U.S.A. page 312-340.

Soulsby, E.J.L. (1982): Helminths, Arthropods and Protozoa of domesticate animals $7^{\text {th }}$ Ed. The English Language Book. Society and Baillier Tindall, London. Pp 795-803.

Veale, P.I. (2002): Resistance to macrocytic lactones in nematodes of goats. Australian Veterinary J., 80, 303-304.

Waller, P.S. (2004): Management and control of nematode parasites of small ruminants in the face of total anthelmintic failure. Tropical biomedicine, 21, 7-13.

Waller, P.S. and Thramborg, S.M. (2004): Nematode control in green ruminant production systems. Trends in Parasitology. 20 (10) 493-497.

Zajac, A.M. and Gipson, T.A. (2000): Multiple anthelmintic resistance in a goat herd. Vetrinary Parasitology, 87, 163-172. 